\title{
BIOSORPTION OF COPPER FROM SYNTHETIC WATERS BY USING TOBACCO LEAF: EQUILIBRIUM, KINETIC AND THERMODYNAMIC TESTS
}

\author{
Mehmet ÇEKIM ${ }^{\mathrm{a}}$, Sayiter YILDIZ ${ }^{\mathrm{b}}$, Turgay DERE ${ }^{\mathrm{c}}$ \\ ${ }^{a}$ Cumhuriyet University, Institute of Science, 58140 Sivas, Turkey \\ ${ }^{b}$ Cumhuriyet University, Engineering Faculty, Department of Environmental Engineering, 58140 Sivas, Turkey \\ 'Adryaman University, Engineering Faculty, Department of Environmental Engineering, \\ 02040 Adryaman, Turkey
}

Submitted 12 Nov. 2014; accepted 08 May 2015

\begin{abstract}
In this study, biosorption of $\mathrm{Cu}^{2+}$ ions on to tobacco leaves was investigated. The optimum conditions for biosorption of $\mathrm{Cu}^{2+}$ ions onto tobacco leaves were determined: $\mathrm{pH}-4.0$, temperature $-20{ }^{\circ} \mathrm{C}$, shaking rate $-200 \mathrm{rpm}$, biosorbent dose $-0.4 \mathrm{~g}$, and initial $\mathrm{Cu}^{2+}$ ion concentration $-25 \mathrm{mg} / \mathrm{L}$. The state of equilibrium lasted for 60 minutes. $\mathrm{COD}, \mathrm{TN}$ and TP analyses were performed to determine the negative impacts of biosorbent on the system. Compliance of equilibrium data of tobacco biosorption of $\mathrm{Cu}^{2+}$ ions to Langmuir, Freundlich, Temkin and D-R isotherm models was also investigated. High correlations were achieved in all four isotherm models. Within the scope of kinetic tests, it was observed that biosorption of $\mathrm{Cu}^{2+}$ ions with tobacco biosorbent complied with the pseudo second-order kinetic rate constant. FTIR, SEM and EDX analyses were carried out to investigate the surface characteristics and chemical structure of tobacco biosorbent and absorption of $\mathrm{Cu}^{2+}$ ions were observed. It was concluded that tobacco leaves are a highly efficient $(90.72 \%)$ sorbent that can remove $\mathrm{Cu}^{2+}$ ions from wastewater.
\end{abstract}

Keywords: biosorption, heavy metal, tobacco, copper, isotherm, kinetic.

\section{Introduction}

Heavy metals are major water pollutants. One of such heavy metals is copper, which can be found as $\mathrm{Cu}(0)$, $\mathrm{Cu}(+)$ and $\mathrm{Cu}(2+)$ in wastewater of various industries, such as metal cleaning and coating, paper, fertilizers etc. $\mathrm{Cu}(2+)$ can easily bind to organic and inorganic substances depending on ambient $\mathrm{pH}$ levels, which makes it especially dangerous (Hasan et al. 2008). In humans, excessive copper intake may cause serious mucosa irritation, problems of the central nervous system, such as depression, and damage of internal organs, such as liver. The threshold $\mathrm{Cu}(2+)$ concentration allowed in drinking water by the World Health Organization is $1.5 \mathrm{mg} / \mathrm{L}$ (Kalavathy et al. 2005).

The traditional methods used to remove heavy metals from aqueous ambient are; chemical precipitation, ion exchange, adsorption through active carbon, reverse osmosis, filtration and membrane technologies (Liu et al. 2004). Ambient metals may not be removed fully through these traditional methods. These techniques have also various disadvantages such as high cost equipment and monitoring system requirements, excessive chemical and energy demands, toxic sludge and other waste material creation (Horsfall et al. 2003). Therefore, biotechnologi$\mathrm{cal}$ approaches are prominent in recent years as alternative treatment methods (Davis et al. 2003).

Biosorption is a physicochemical process that occurs naturally in certain biomass which allows it to passively concentrate and bind contaminants onto its cellular structure (Churchill et al. 1995). In other words, biosorption is a process that can be explained by adsorption principles and is used to remove heavy metal ions, radioactive elements and dyes through inactive biomass (Özer et al. 2009).

In biosorption, physicochemical principles of metal bindings onto cellular structure are composed of complexation, coordination, chelate formation, ion exchange, adsorption and inorganic micro precipitation processes. In general, ion exchange is the vastly observed mechanism (Volesky 2001). Biosorption process has various advantages such as low operational costs, relative low waste sludge volumes, easy-use of waste materials, seaweeds, natural

Corresponding author: Sayiter Ylldız

E-mail: sayildiz@cumhuriyet.edu.tr 
substances or raw biosorbents obtained from the other industrial activities (fermentation wastes), recycle of the metals over biosorbent and waste material (Wang, Chen 2006).

In this study, removal of $\mathrm{Cu}^{2+}$ ions from synthetic wastewater by using tobacco leaf through biosorption in an intermittent system was investigated. The effects of ambient $\mathrm{pH}$, initial metal concentration, initial biosorbent concentration, duration of contact, shaking rate and temperature parameters on biosorption were investigated through isotherm, kinetic and thermodynamic assessments. Variations in chemical oxygen demand (COD), total nitrogen (TN) and toplam phosphorus (TP) values of tobacco-leaf biosorption system were also investigated. Additionally, Fourier Transform Infrared Spectroscopy (FT-IR), Scanning Electron Microscope (SEM) and Energy Dispersive X-Ray (EDX) analyses were also performed over experimental data.

\section{Material and methods}

\subsection{Biosorbent preparation}

Tobacco leaves to be used in biosorption tests were supplied from tobacco fields of Pınarbaşı town of Adıyaman Province. The leaves were washed with distilled water until they totally lose their color and dried in an oven at $105^{\circ} \mathrm{C}$ for 24 hours. Dried leaves were then grinded and made active through keeping inside $1 \% \mathrm{H}_{2} \mathrm{SO}_{4}$ solution for 24 hours. Activated absorbent washed and filtrated again with distilled water to remove the acid content and dried at $105{ }^{\circ} \mathrm{C}$ for 24 hours. The resultant dried tobacco leaves sieved through $0.30 \mathrm{~mm}$ sieve and made ready for experiments.

\subsection{Preparation of copper solution}

$\mathrm{Cu}^{2+}$ solution was prepared by using sufficient $(3.929 \mathrm{~g}$ ) amount of copper sulphate $\left(\mathrm{CuSO}_{4} \cdot 5 \mathrm{H}_{2} \mathrm{O}\right)$ chemical as to have a solution at $1 \mathrm{~L}$ in volume and $1000 \mathrm{mg} / \mathrm{L}$ in concentration. Different metal ion concentrations were prepared by making relevant dilutions from the stock solution.

\subsection{Experimental setup and method of analysis}

Biosorption tests were carried in in $250 \mathrm{~mL}$ Erlenmeyer flasks in an intermittent system by using $100 \mathrm{~mL}$ copper solution and biosorbent. Wise Shake (SHO-2D) shaking incubator able to operate at constant temperature and shaking rate was used in biosorption tests. The time at which biosorbent added to copper solution is assumed to be $t=0$ and analyses were performed at certain intervals. Free $\mathrm{Cu}^{2+}$ ions were read in samples to find out the absorbance at $478 \mathrm{~nm}$ wave length and analyzed in a HachLange DR-6000 UV spectrophotometer. During the tests, $\mathrm{pH}$ values were read by Thermo Orion - STARA2145 brand $\mathrm{pH}$ meter. The $\mathrm{pH}$ levels were adjusted separately with concentrated and diluted $\mathrm{H}_{2} \mathrm{SO}_{4}$ and $\mathrm{NaOH}$. Chemical oxygen demand (COD), total nitrogen (TN) and total phosphorus (TP) analyses were performed by using HachLange instant kits. Biosorption capacity $\left(q_{e}\right)$ and percent removal efficiency (yield) were calculated by using the following equations:

$$
\begin{gathered}
q_{e}=\frac{V\left(C_{o}-C_{e}\right)}{X} ; \\
(E) \%=\frac{\left(C_{o}-C_{e}\right)}{C_{o}} \cdot 100,
\end{gathered}
$$

where: $q_{e}(\mathrm{mg} / \mathrm{g})$ is the concentration of the substances bound over adsorbent; $X(\mathrm{~g})$ is the amount of adsorbent used in tests; $V(\mathrm{~mL})$ is the solution volume; $C_{o}(\mathrm{mg} / \mathrm{L})$ is the initial concentration of the solution; $C_{e}(\mathrm{mg} / \mathrm{L})$ is the final concentration of the solution.

Compliance of the experimental data with Langmuir, Freundlich, Temkin and D-R isotherm models were investigated. In Langmuir isotherm, adsorption linearly increase with the initial concentration of the adsorbed material (Aksu, Akpinar 2000). Langmuir isotherm equation is provided below (Eq. 3):

$$
q_{e}=\frac{Q_{\max } K_{a} C_{e}}{1+K_{a} C_{e}},
$$

where: $q_{e}$ is the amount of adsorbed material over a unit adsorbent ( $\mathrm{mg} / \mathrm{g}), Q_{\max }$ is Langmuir isotherm constant expressing the maximum amount of material to be adsorbed over the sorbent under operational conditions $(\mathrm{mg} / \mathrm{g})$, $K_{a}$ is Langmuir constant expressing adsorption energy (L/mg), $C_{e}$ is the concentration of material left within the solution following the adsorption $(\mathrm{mg} / \mathrm{L})$.

Dimensionless $R_{L}$ (dispersion) coefficient is calculated to find out the availability of biosorption (Eq. 4) and a value between 0 and 1 indicates the availability of the adsorption (Başıüyük, Forster 2003):

$$
R_{L}=\frac{1}{1+K_{a} C_{o}} .
$$

Freundlich isotherm assumes that the amount of adsorbed material increase with the increasing concentration of adsorbed material in solution (Weber 1972). Freundlich isotherm model is expressed by Equation (5):

$$
q_{e}=K_{F} C_{e}^{\left(\frac{1}{n}\right)}
$$

where $K_{F}$ and $n$ are constants depending on temperature, adsorbent and adsorbed material. $K_{F}$ is called as adsorption capacity and the term $1 / n$ is called as heterogeneity factor. This isotherm can successfully be used to define heterogeneous systems (Ghoreishi, Haghighi 2003).

According to linearized Freundlich equation (Eq. 6), a graph is drawn with $\ln$ Ce versus $\ln q_{e}$. The term $1 / n$ is 
derived from the slope and $\ln K_{F}$ is taken from the interception point on $\mathrm{y}$-axis:

$$
\ln q_{e}=\ln K_{F}+(1 / n) \ln C_{e} .
$$

Temkin model was developed by considering adsorption temperature of entire molecules within the layer and linearly decrease because of the area influenced by adsorbent interactions (Kılıç et al. 2011). The equation expressing Temkin isotherm is provided in Eq. (7) (Allen et al. 2004):

$$
q_{e}=\left(\frac{R T}{b}\right) \ln \left(A \cdot C_{e}\right)
$$

where: $R$ is gas constant $(\mathrm{J} / \mathrm{mol} \mathrm{K}), T$ is temperature $(\mathrm{K})$, and $A$ is Toth constant $\left(\mathrm{dm}^{3} / \mathrm{g}\right)$. When this equation is linearized and the term $(R T / b)$ in this equation is expressed as $B$, Equation (8) is obtained. $B$ is related to adsorption temperature of Temkin isotherm constant (Allen et al. 2003):

$$
q_{e}=B \ln A+B \ln C_{e} .
$$

The constants obtained from Langmuir and Freundlich isotherms do not provide any information about the physical and chemical characteristics of biosorption. However, average adsorption energy (E) calculated with $\mathrm{D}-\mathrm{R}$ isotherm developed by Dubinin and Radushkevich (Dubinin, Radushkevich 1947) provide information about physical and chemical characteristics of the sorption (Ceyhan, Baybaş 2001). D-R isotherm is expressed by Equation (9) provided below (Sar1 et al. 2008; Malik et al. 2005):

$$
\ln q_{e}=\ln q_{\max }-\beta \varepsilon^{2} .
$$

The amount adsorbed $\left(q_{e} ; \mathrm{mol} / \mathrm{g}\right)$ is related to maximum sorption capacity $\left(q_{\mathrm{D}-\mathrm{R}} ; \mathrm{mol} / \mathrm{g}\right)$, average adsorption energy (E) and relevant activity coefficient $\left(\beta ; \mathrm{mol}^{2} / \mathrm{J}^{2}\right)$ and is a function of Polanyi potential $(\varepsilon)$. The Polanyi potential (ع) is calculated by using Equation (10) (Sar1 et al. 2008):

$$
\varepsilon=R T \ln \left(1+\frac{1}{C_{e}}\right) .
$$

Maximum holding capacity $q_{\mathrm{D}-\mathrm{R}}$ and $\beta$ can be calculated from the $q_{e}-\varepsilon^{2}$ graph of the model drawn by the experimental data. Adsorption energy $(\mathrm{E} ; \mathrm{kJ} / \mathrm{mol})$ is calculated by using the Equation (11) (Sar1 et al. 2008):

$$
E=\frac{1}{\sqrt{-2 \beta}} \text {. }
$$

\subsection{Biosorption kinetics}

Kinetic tests were performed at $\mathrm{pH}$ levels of 2-3-4-5 for 1-60 minutes to determine the relations of $\mathrm{Cu}^{2+}$ ion biosorption onto tobacco sorbent with duration of contact at different $\mathrm{pH}$ levels. Compliance of the resultant data with the pseudo first-order and second-order kinetic models was assessed. The kinetic models and expressions used in these tests are provided below:

Pseudo First-Order Kinetic Model: Pseudo first-order rate equation was derived by Lagergren and rate equation is provided below (Ho, Chiang 2001):

$$
\log \left(q_{e}-q_{t}\right)=\log \left(q_{e}\right)-\frac{k_{1}}{2.303} \cdot t
$$

where: $k_{1}$ is rate constant $(1 / \mathrm{min}), q_{e}$ is adsorption capacity $(\mathrm{mg} / \mathrm{g}), q_{t}$ is adsorbed material concentration at time $t$ $(\mathrm{mg} / \mathrm{g})$.

When the graph of $\log \left(q_{e}-q_{t}\right)$ versus $t$ is drawn according to Eq. (12), the slope of the line provides $k_{1} / 2.303$ and $y$-axis interception point provides $\log \left(q_{e}\right)$. Relevant calculations are then performed to find $k_{1}$ and $q_{e}$ values.

Pseudo Second-Order Rate Equation: The pseudo second-order rate equation developed by Ho in 1995 expressed independency of the rate from adsorbent concentration and dependency to adsorption capacity at solid phase and time (Ho, Wang 2004). Pseudo second-order rate equation is provided in Eq. (13) (Ip et al. 2010):

$$
\frac{t}{q_{t}}=\frac{k_{1}}{k_{2}\left(q_{e}\right)^{2}}+\frac{1}{q_{e}} \cdot t
$$

where: $k_{2}$ is pseudo second-order rate constant (g/mg.min), $q_{e}$ is the amount of adsorbed material at equilibrium ( $\mathrm{mg} / \mathrm{g}), q_{t}$ is the material concentration adsorbed at time $t(\mathrm{mg} / \mathrm{g})$. When the graph of $\left(t / q_{t}\right) v s t$ is drawn according to equation, slope of the line provides $1 / q_{e}$ and $y$-axis interception point provides $1 / k\left(q_{e}\right)^{2}$ value.

Inter-Particle Diffusion (Weber-Morris) Model: in case the diffusion mechanism is not explained clearly by the pseudo first and second-order equations, kinetic results are tried to be explained by inter-particle diffusion model (Kilıç et al. 2011). Inter-particle diffusion rate equation is provided in Eq. (14) (Ghasemi et al. 2012):

$$
q_{t}=k_{i d}(t) 0.5+C \text {, }
$$

where: $k_{i d}$ is inter-particle diffusion constant $\left(\mathrm{mg} \cdot \mathrm{g}^{-1} \cdot \mathrm{min}^{-0.5}\right)$, $t$ is time (minute), $C$ is the thickness of boundary layer in adsorption duration (Polat, Aslan 2014). When the graph of $q t$ versus $t^{0.5}$ is drawn, the slope of the line provides $k_{i d}$ adsorption constant.

\subsection{Thermodynamic tests}

Thermodynamics allows the researchers to gain knowledge about thermal events accompanying chemical reactions, thermal characteristics of reaction materials, especially about entropy and enthalpy, general criteria about volition of reactions and equilibrium (Pahlavanzadeh 
et al. 2010). Thermodynamic parameters are provided in Eqs 15-16:

$$
\Delta G^{0}=\Delta H^{0}-T \Delta S^{0},
$$

where: $\Delta G^{0}$ : Gibbs free energy $(\mathrm{kJ} / \mathrm{mol}), \Delta H^{0}$ is enthalpy exchange $(\mathrm{kJ} / \mathrm{mol}), \Delta S^{0}$ is entropy exchange $(\mathrm{kJ} / \mathrm{mol} \mathrm{K}), T$ is absolute temperature (Kelvin):

$$
\ln K_{c}=\frac{\Delta G^{0}}{R}+\frac{\Delta H^{0}}{R T} .
$$

Gibbs free energy value of adsorption process carried out at a certain temperature is calculated with $K_{c}$ by using the equation $\Delta G^{0}=-R T \ln K_{c}(R=8.314 \mathrm{~J} / \mathrm{mol} \mathrm{K})$. Then the graph of $\ln K_{c}$ versus $1 / T$ is drawn and $\Delta H^{0}$ and $\Delta S^{0}$ can be calculated by using the slope and interception point. $K_{c}$ is the ratio of adsorbed $\mathrm{Cu}^{2+}$ concentration to residual $\mathrm{Cu}^{2+}$ concentration in solution.

Sorption experiments were performed in triplicate and the average values of samples were presented. Also, blank samples (without $\mathrm{Cu}^{2+}$ ) were used to compare the results through all batch procedures. Data presented are the mean values from the experiments, standard deviation $(\leq 2 \%)$ and error bars are indicated in figures.

\section{Results and discussion}

\subsection{Biosorbent characterization}

\section{FT-IR analyses}

In several previous studies, raw biomass and metal-loaded biomass spectrums of Fourier Transform InfraRed (FTIR) spectrum analyses were compared to explain biosorption process between biomass and metal ions (Pradhan et al. 2007). FT-IR spectrums of tobacco leaves were taken to investigate the changes in functional groups before and after the biosorption of $\mathrm{Cu}^{2+}$ ions (Fig. 1).

It was observed that wavelength absorbances and intensities of two spectrums obtained before and after biosorption process were different. Absorbances of $\mathrm{C}=\mathrm{O}$ strains of carboxyl groups over $1614.41 \mathrm{~cm}^{-1}$ and $1434.56 \mathrm{~cm}^{-1}$, assumed to play a role especially in binding $\mathrm{Cu}^{2+}$ ions, were respectively observed as $1614.48 \mathrm{~cm}^{-1}$ and $1429.52 \mathrm{~cm}^{-1}$ after biosorption process. Such a case indicated the existence of broad-band hydroxyl groups $(-\mathrm{OH})$ observed between 3000-3750 $\mathrm{cm}^{-1}$ (Yazıc1 2007). Right at this strain point, the absorbance value of $3356.75 \mathrm{~cm}^{-1}$ before the biosorption changed to $3291.26 \mathrm{~cm}^{-1}$ after the biosorption. The other bands around 2925 and $2893 \mathrm{~cm}^{-1}$ indicate symmetric strain vibrations in alkyl $\left(-\mathrm{CH}_{3}\right.$ or $-\mathrm{CH}^{2-}$ ) groups (Majumdar et al. 2008). At this point, the absorbance value of $2920.92 \mathrm{~cm}^{-1}$ changed as $2918.08 \mathrm{~cm}^{-1}$.

The increases and decreases (especially the decreases) in FT-IR spectrums after the adsorption process are considered as the indications of participation of these active groups in adsorption process.

\section{SEM (Scanning Electron Microscope) and EDX analyses}

SEM (Scanning Electron Microscope) was used to take SEM images of the sorbent before and after the biosorption process and to determine whether or not $\mathrm{Cu} 2+$ ions are adsorbed onto tobacco biosorbent (Fig. 2).

Color coding of the elements within green rectangular in SEM images (Fig. 2) are presented in Figure 3. As it can be seen from Figure 3, $\mathrm{Cu}^{2+}$ metal was adsorbed onto biosorbent surface with a red color code.

EDX (Energy dispersive X-ray) detector of SEM device was used to make element analyses of tobacco biosorbent before and after the biosorption and different colors

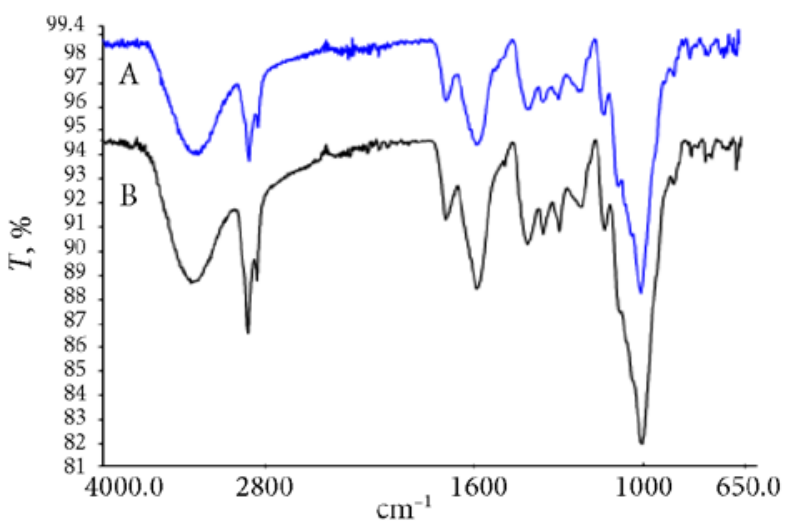

Fig. 1. (a) FT-IR spectrum of tobacco leaf after biosorption and (b) FT-IR spectrum of tobacco leaf before biosorption

a)

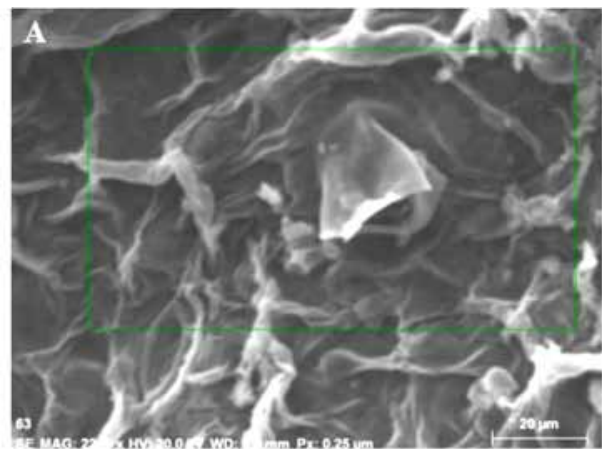

b)

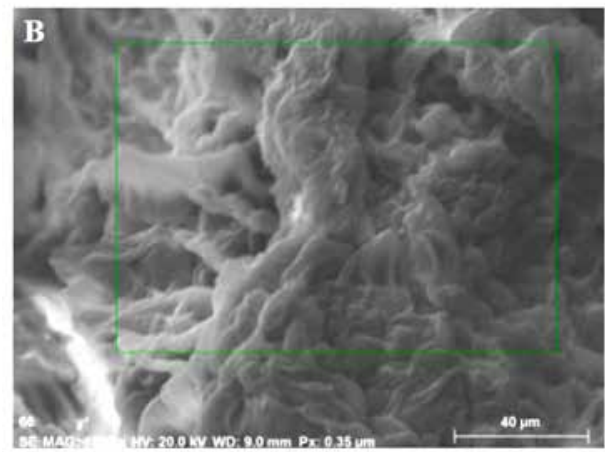

Fig. 2. (a) SEM images of tobacco leaf before biosorption (b) SEM images of tobacco leaf after biosorption 
a)

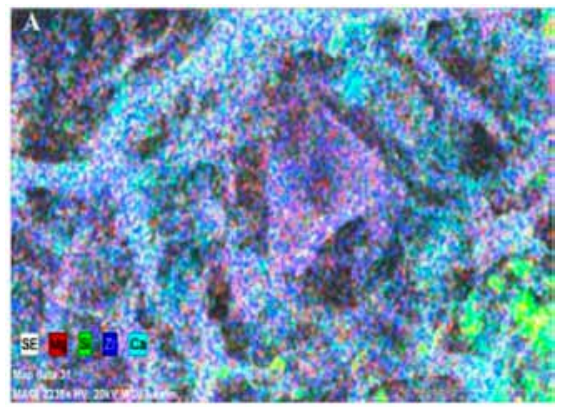

b)

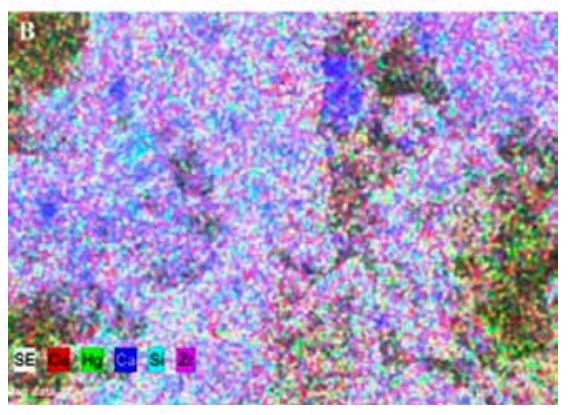

Fig. 3. (a) Element distributions of EDX analysis region before biosorption (b) Element distributions of EDX analysis region after biosorption

a)

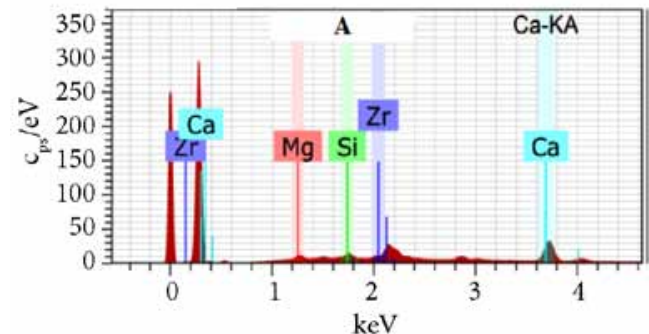

b)

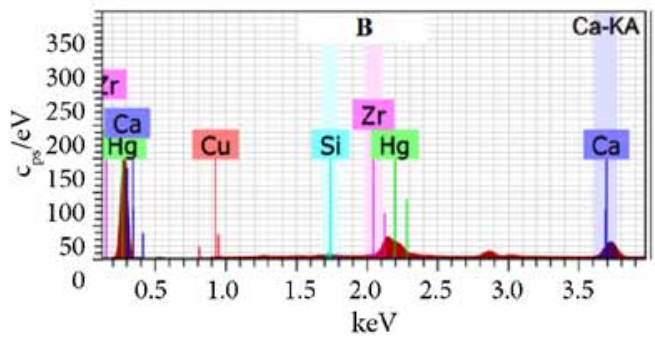

Fig. 4. (a) EDX results of tobacco leaf before biosorption (b) EDX results of tobacco leaf after biosorption

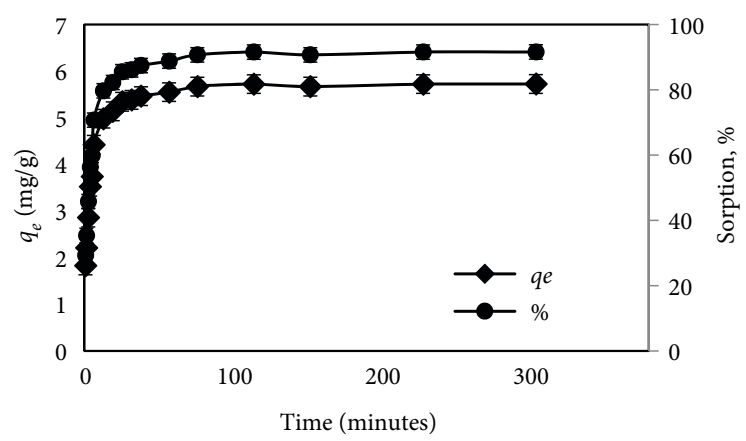

Fig. 5. Variation of biosorption capacity and yield with contact time were coded (Fig. 4). Figures revealed that copper did not exist in EDX analysis before biosorption. However, EDX analyses after biosorption revealed that copper ions were adsorbed.

\subsection{Biosorption equilibrium duration}

Initial concentration (Co) was selected as $25 \mathrm{mg} / \mathrm{L}$ to determine the equilibrium duration of $\mathrm{Cu}^{2+}$ biosorption. Other ambient conditions were set as; biosorbent dose $(X)=0.4 \mathrm{~g}$, shaking rate $=200 \mathrm{rpm}, \mathrm{pH}=4$. Resultant outcomes are presented in Figure 5.

Results revealed a rapid $\mathrm{Cu}^{2+}$ ion binding onto biosorbent during the initial 5 minutes (70\%). The highest biosorbent capacity was achieved in 60 minutes. Later on, significant changes were not observed. Therefore, equilibrium duration was determined to be 60 minutes.

\subsection{Effects of $\mathrm{pH}$ on $\mathrm{Cu}+2$ biosorption}

Previous biosorption tests revealed that ambient $\mathrm{pH}$ had significant impacts on biosorption capacity (Al-Rub et al. 2004; Keskinkan et al. 2004; Gong et al. 2005; Lodeiro et al. 2005). Tests were carried out in this study with $\mathrm{pH}$ values in between $2-5$ in 0.5 unit increments.

While the yield was $43 \%$ at $\mathrm{pH}$ of 2 , the value increased to $86 \%$ at $\mathrm{pH}$ of 3 . The sorption capacity $\left(q_{e}\right)$ was 5.58 at $\mathrm{pH}$ of 3.5 , whereas the value was 5.72 at $\mathrm{pH}$ of 5 .

COD analyses were carried out to determine the amount of organic pollutants provided to the ambient with the changing $\mathrm{pH}$ levels. Increased COD levels were observed when the $\mathrm{pH}$ of the ambient is around 2. However, there were not significant changes in COD levels after the $\mathrm{pH}$ level of 2.5. Results revealed that tobacco sorbent increased COD level of the ambient (239-363 mg/L).

\subsection{Effects of copper concentration on biosorption}

There are several studies in literature indicating increasing biosorption capacities with increasing initial metal concentrations (Gülnaz et al. 2005). Similarly, increased biosorption capacities $\left(q_{e}\right)$ were observed in the present study with increasing initial $\mathrm{Cu}^{2+}$ concentrations (Fig. 6a). The highest $q_{e}$ value $(10.66 \mathrm{mg} / \mathrm{g})$ was observed at initial $\mathrm{Cu}^{2+}$ concentration of $50 \mathrm{mg} / \mathrm{L}$. The highest removal efficiency at $\mathrm{Cu}^{2+}$ concentrations of $10-15-20 \mathrm{mg} / \mathrm{L}$ was observed as $92 \%$. Although the highest $q_{e}$ value was achieved at $50 \mathrm{mg} / \mathrm{L}$, the lowest removal efficiency $(85 \%)$ was also observed at this concentration.

\subsection{Effects of biosorbent quantity}

Significant effects of biosorbent quantity on biosorption capacity and yield were reported in previous biosorption studies (Al-Qodah 2006; Ju et al. 2008). The tests were carried out in this study with biosorbent quantities of $1-8 \mathrm{~g} / \mathrm{L}$ 

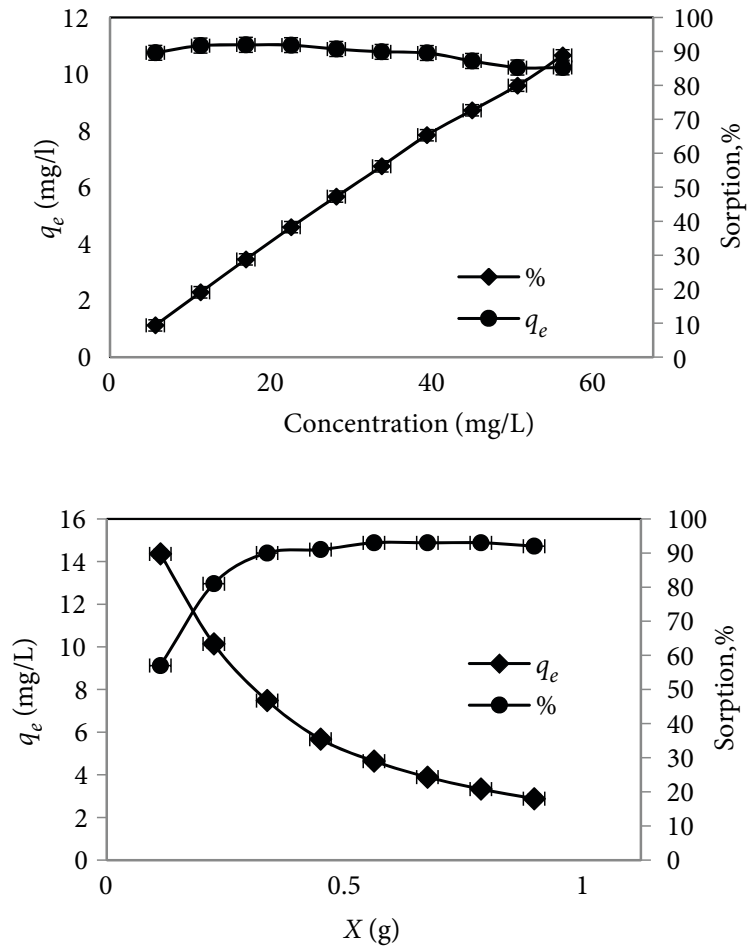

Fig. 6. (a) Effects of initial $\mathrm{Cu}^{2+}$ concentrations on biosorption capacity and yield (b) Effects of biosorbent quantity on biosorption capacity and yield

to determine the effects of biosorbent quantity on $\mathrm{Cu}^{2+}$ ion biosorption onto tobacco sorbent (Fig. 6b). The highest yield at $5-6-7 \mathrm{~g} / \mathrm{L}$ sorbent rates was observed as $93 \%$. Percent removal at $1 \mathrm{~g} / \mathrm{L}$ biosorbent rate was determined to be $57 \%$ and biosorbent capacity was determined to be $14.36 \mathrm{mg} / \mathrm{g}$.

Effects of changing biosorbent quantities on COD, TN and TP levels of the solution were also investigated in this study. COD, TN and TP values at $8 \mathrm{~g} / \mathrm{L}$ biosorbent quantity were respectively observed as $399 \mathrm{mg} / \mathrm{L}$, $5.37 \mathrm{mg} / \mathrm{L}$ and $5.33 \mathrm{mg} / \mathrm{L}$. Same values at $1 \mathrm{~g} / \mathrm{L}$ biosorbent were respectively determined to be $88 \mathrm{mg} / \mathrm{L}, 1.66 \mathrm{mg} / \mathrm{L}$ and $0.771 \mathrm{mg} / \mathrm{L}$. Results revealed increasing COD, TN and TP levels with increasing biosorbent quantities.

\subsection{Effects of shaking rate on biosorption}

The yields varied between $90-91 \%$ and $q_{e}$ values varied between $5.60-5.70 \mathrm{mg} / \mathrm{g}$ at shaking rates between $100-300 \mathrm{rpm}$. It was determined that shaking rates over $100 \mathrm{rpm}$ did not have significant impacts on biosorption process (Ho, McKay 1999).

\subsection{Effects of temperature on biosorption}

Tests were carried out at temperatures in between $20-50{ }^{\circ} \mathrm{C}$ to determine the effects of temperature on biosorption. While biosorption capacity was $5.74 \mathrm{mg} / \mathrm{g}$ at $20{ }^{\circ} \mathrm{C}$, the value was $5.55 \mathrm{mg} / \mathrm{g}$ at $50{ }^{\circ} \mathrm{C}$. Biosorption capacity $\left(q_{e}\right)$ varied between $5.55-5.74 \mathrm{mg} / \mathrm{g}$ and yield values varied between $89-91 \%$ at temperatures in between $20-50{ }^{\circ} \mathrm{C}$. While some previous studies indicated linear increases in biosorption capacities with increasing temperatures (Polat, Aslan 2014; Martins et al. 2004), others indicated decreasing biosorption capacities with increasing temperatures (Aksu 2001; Cruz et al. 2004). Some others indicated that temperature did not have any significant effects on biosorption process (Topal et al. 2011; Güler, Sarığlu 2013). Similarly, significant effects of temperature on biosorption system were not observed in this study.

COD analyses were performed to assess the effects of temperature on organic pollutants released to ambient. Results revealed that temperature did not have any significant impacts of COD release to ambient. COD levels varied between $208-235 \mathrm{mg} / \mathrm{L}$ with varying temperatures.

\subsection{Isotherm models}

The data obtained at different initial $\mathrm{Cu}^{+2}$ concentrations were fitted to Langmuir, Freundlich, Temkin and D-R (Dubinin-Radushkevich) models. The coefficients for these models are provided in Table 1. $Q_{\max }$ indicates the maximum biosorption capacity of tobacco $(\mathrm{mg} / \mathrm{g}) . K_{a}$ is Langmuir constant $(\mathrm{L} / \mathrm{mg})$ and indicates affinity of adsorbent related to biosorption enthalpy to biosorbent and the strength of the tie between them. $K_{F}$ expresses biosorption capacity $(\mathrm{L} / \mathrm{g}), n$ expresses intensity of biosorption. High $K_{F}$ and $n$ values indicate higher affinity of biosorbent to biosorption and desired levels of biosorption process.

Table 1. Sorption parameters and correlation coefficients for different models

\begin{tabular}{|c|c|c|c|}
\hline Model & Equation & \multicolumn{2}{|c|}{ Sorption Parameters } \\
\hline Langmuir & $\begin{array}{l}1 / q_{e}=\left(1 / Q_{\max } K_{a}\right) \\
\left(1 / C_{e}\right)+\left(1 / Q_{\max }\right)\end{array}$ & $\begin{array}{l}R^{2} \\
K_{a}(\mathrm{~L} / \mathrm{mg}) \\
Q_{\max }(\mathrm{mg} / \mathrm{g}) \\
R_{L}\end{array}$ & $\begin{array}{c}0.995 \\
0.213 \\
17.182 \\
0.158 \\
\end{array}$ \\
\hline Freundlich & $\begin{array}{l}\ln q_{e}=\ln K_{F}+(1 / n) . \\
\ln C_{e}\end{array}$ & $\begin{array}{l}R^{2} \\
K_{F}(\mathrm{~L} / \mathrm{g}) \\
n\end{array}$ & $\begin{array}{l}0.979 \\
3.361 \\
1.700\end{array}$ \\
\hline Temkin & $\begin{array}{l}q_{e}=B \ln A+ \\
B \ln C_{e}\end{array}$ & $\begin{array}{l}R^{2} \\
A(\mathrm{~L} / \mathrm{g}) \\
B\end{array}$ & $\begin{array}{l}0.991 \\
1.994 \\
3.824\end{array}$ \\
\hline $\mathrm{D}-\mathrm{R}$ & $\ln q_{e}=\ln q_{\max }-\beta \varepsilon^{2}$ & $\begin{array}{l}R^{2} \\
\beta\left(\mathrm{mol}^{2} / \mathrm{j}^{2}\right) \\
q_{\max }(\mathrm{mg} / \mathrm{g}) \\
E(\mathrm{kj} / \mathrm{mol})\end{array}$ & $\begin{array}{c}0.937 \\
-0.499 \\
9.606 \\
1.001\end{array}$ \\
\hline
\end{tabular}

As it can be seen from Table 1, correlation coefficients were relatively high in all models. The highest value was observed in Langmuir isotherm with $R^{2}=0.995$. Maximum biosorbent capacity of Langmuir isotherm model was $17.182 \mathrm{mg} / \mathrm{g}$, dimensionless $R_{L}$ coefficient was calculated as 0.158 . This $R_{L}$ value indicated that tobacco is 


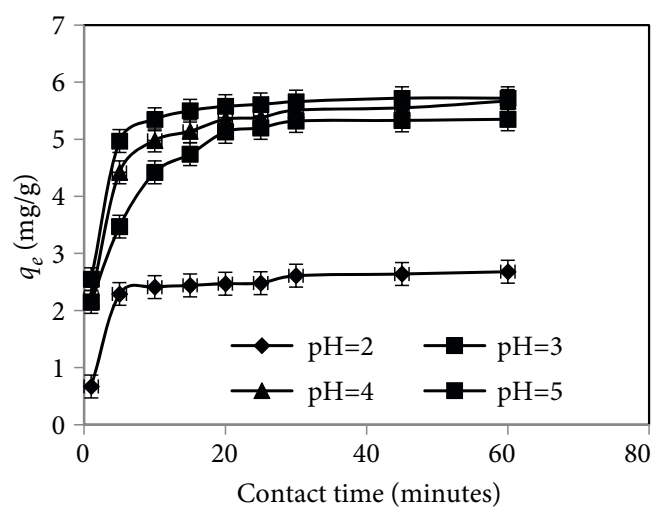

Fig. 7. Variation of biosorption capacity with contact durations at different $\mathrm{pH}$ levels

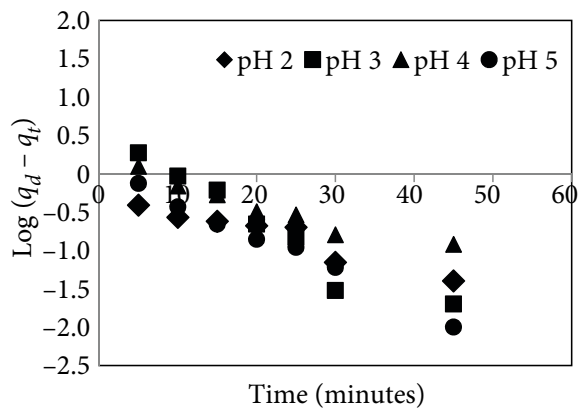

Fig. 8. Graphs of pseudo first - order kinetic models for biosorption of $\mathrm{Cu}^{2+}$ ions onto tobacco

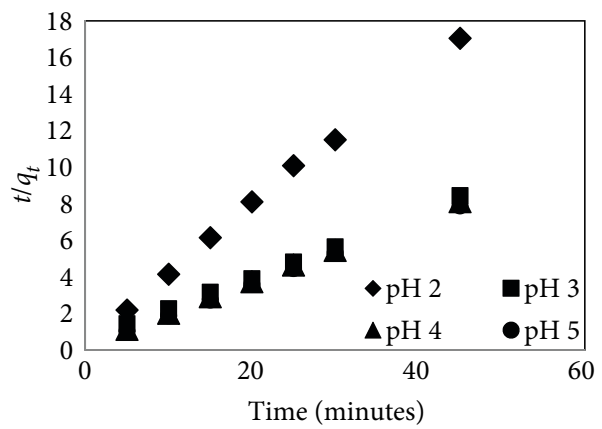

Fig. 9. Graphs of pseudo second-order kinetic models for biosorption of $\mathrm{Cu}^{2+}$ ions onto tobacco

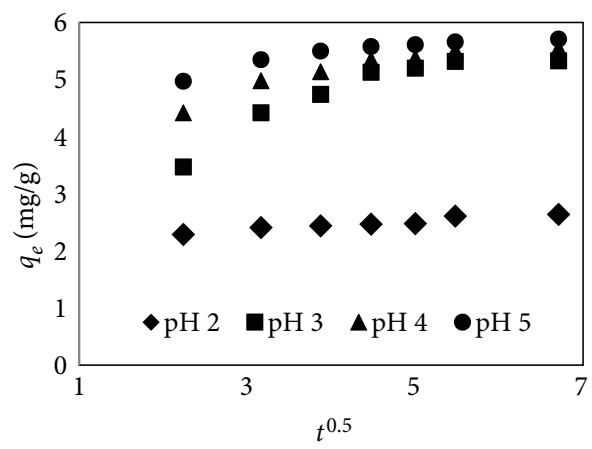

Fig. 10. Graphs of Weber-Morrisi for biosorption of $\mathrm{Cu}^{2+}$ ions onto tobacco an available sorbent for biosorption of $\mathrm{Cu}^{2+}$ ions (Doğan, Alkan 2003).

It was asserted that entire molecules at adsorption layer of Temkin isotherm decreased linearly with adsorption temperature. In this isotherm model, effects of indirect adsorbed/adsorbed interactions on adsorption isotherms are investigated (Temkin, Phyzev 1940). The highest $R^{2}$ (0.991) value was also observed in Temkin isotherm model and $B$ Temkin isotherm constant related to adsorption temperature was calculated as 3.824 .

In D-R model, adsorption energy $(E)$ was calculated as $1.001 \mathrm{kj} / \mathrm{mol}, q_{\max }$ as $9.606 \mathrm{mg} / \mathrm{g}$ and $\beta$ value as $-0.499 \mathrm{~mol}^{2} / \mathrm{j}^{2}$. Of these values, adsorption energies $(E)$ between $8-16 \mathrm{kj} / \mathrm{mol}$ indicated that sorption mainly realized through ion exchange mechanism which is a chemical process. $E$ values lower than $8 \mathrm{kj} / \mathrm{mol}$ indicates physi$\mathrm{cal}$ interactions as the binding mechanisms (Sawalha et al. 2006). In the present study, binding mechanisms may be explained by physical interactions $(E=1.001 \mathrm{kj} / \mathrm{mol}<$ $8 \mathrm{kj} / \mathrm{mol}$ ).

\subsection{Kinetic constants}

Kinetic tests were carried out at $\mathrm{pH}$ levels of $2-3-4-5$ and for durations of 1-60 minutes (Fig. 7). Compliance of data with pseudo first-order (Fig. 8) and pseudo second-order (Fig. 9) kinetic models and inter-particle diffusion model (Fig. 10) were assessed. The pseudo first and second order rate constants $\left(k_{1}\right.$ and $\left.k_{2}\right)$, amount of $\mathrm{Cu}^{2+}$ adsorbed by a unit biosorbent at equilibrium $\left(q_{d}\right.$, teo), initial sorption rate ( $h ; \mathrm{mg} / \mathrm{g} . \mathrm{dk}$ ), inter-particle (Weber-Morris model) diffusion rate constant $k_{i}(\mathrm{mg} / \mathrm{g} \cdot \mathrm{dk} 0.5)$ are provided in Table 2 .

Previous studies indicated relatively low correlations and high errors for the pseudo first and second-order kinetic models (Ho, McKay 1999). As it can be seen from the Table 2, almost identical values of theoretical and experimental $q_{d}$ values for the pseudo first and secondorder kinetic models indicated a well compliance. While the greatest $k_{2}$ value was observed at $\mathrm{pH}$ of 2 , the lowest $k_{2}$ value was obtained from $\mathrm{pH}$ of 3 . The highest $R^{2}$ and sorption rate values at $\mathrm{pH} 4$ and 5 were respectively observed as $0.9999-0.9999$ and $3.5442-6.4465 \mathrm{mg} / \mathrm{g} \cdot \mathrm{dk}$.

\subsection{Calculation of thermodynamic parameters}

The graph of $\ln K_{c}$ versus $1 / T$ for different temperatures is presented in Figure 11 and calculated thermodynamic parameters are provided in Table 3.

A negative Gibbs free energy indicates spontaneous biosorption, a positive value indicates nonspontaneous biosorption and a value of zero indicates equilibrium biosorption (Aksu 2002). In Table 3, Gibss energy of $\mathrm{Cu}^{2+}$ ions $\left(\Delta \mathrm{G}^{0}\right)$ was negative (-). Negative (-) $\Delta \mathrm{G}^{0}$ indicated spontaneous biosorption. 
A positive biosorption entalphy $\left(\Delta H^{0}\right)$ value indicates that the system received energy from an external source, in other words the system was endothermic (Ho 2003). Negative $\Delta S^{0}$ value indicates metal ion affinity to biosorbent at solid-solution interspace or a more regular state of metal ion over biosorbent surface (Padmavathy 2008).

Comparisons of $\mathrm{Cu}^{2+}$ biosorption studies carried out with different sorbents are provided in Table 4.

Table 2. Kinetic constant for biosorption of $\mathrm{Cu}^{2+}$ ions onto tobacco

\begin{tabular}{|c|c|c|c|c|}
\hline \multirow[b]{2}{*}{$\mathrm{pH}$} & \multirow[b]{2}{*}{$q_{d, d e n}$} & \multicolumn{3}{|c|}{ Pseudo-first-order } \\
\hline & & $k_{1}$ & $\begin{array}{c}q_{d, \text { teo }} \\
(\mathrm{mg} / \mathrm{g})\end{array}$ & $R^{2}$ \\
\hline 2 & 2.68 & 0.058 & 0.558 & 0.911 \\
\hline 3 & 5.35 & 0.123 & 2.979 & 0.930 \\
\hline 4 & 5.67 & 0.059 & 1.276 & 0.927 \\
\hline 5 & 5.72 & 0.103 & 1.166 & 0.990 \\
\hline \multirow[b]{2}{*}{$\mathrm{pH}$} & \multicolumn{4}{|c|}{ Pseudo-second-order } \\
\hline & $k_{2}$ & $\begin{array}{c}q_{d, d e n} \\
(\mathrm{mg} / \mathrm{g})\end{array}$ & $\begin{array}{c}h \\
(\mathrm{mg} / \mathrm{g} \cdot \mathrm{dk}) \\
\end{array}$ & $R^{2}$ \\
\hline 2 & 0.262 & 2.701 & 1.879 & 0.998 \\
\hline 3 & 0.060 & 5.744 & 1.718 & 0.998 \\
\hline 4 & 0.110 & 5.754 & 3.544 & 0.999 \\
\hline 5 & 0.197 & 5.821 & 6.447 & 0.999 \\
\hline \multicolumn{5}{|c|}{ Inter-Particle Diffusion (Weber-Morris) } \\
\hline $\mathrm{pH}$ & $\begin{array}{c}k_{i} \\
\left(\mathrm{mg} / \mathrm{g} \cdot \mathrm{dk}^{0.5}\right) \\
\end{array}$ & $C$ & \multicolumn{2}{|c|}{$R^{2}$} \\
\hline 2 & 0.077 & 2.137 & \multicolumn{2}{|c|}{0.930} \\
\hline 3 & 0.407 & 3.004 & \multicolumn{2}{|c|}{0.806} \\
\hline 4 & 0.244 & 4.113 & \multicolumn{2}{|c|}{0.850} \\
\hline 5 & 0.155 & 4.799 & \multicolumn{2}{|c|}{0.819} \\
\hline
\end{tabular}

Table 3. $K, \Delta G^{0}, \Delta H^{0}$ and $\Delta S^{0}$ values of $\mathrm{Cu}^{2+}$ ions at different temperatures

\begin{tabular}{ccccc}
\hline $\begin{array}{c}\text { Tempe- } \\
\text { rature }\left({ }^{\circ} \mathrm{C}\right)\end{array}$ & $K_{c}$ & $\begin{array}{c}\Delta G^{0} \\
(\mathrm{kj} / \mathrm{mol})\end{array}$ & $\begin{array}{c}\Delta H^{0} \\
(\mathrm{kj} / \mathrm{mol})\end{array}$ & $\begin{array}{c}\Delta S^{0} \\
(\mathrm{kj} / \mathrm{molK})\end{array}$ \\
\hline 20 & 11.3153 & -5.91011 & & \\
25 & 9.7759 & -5.64866 & & \\
30 & 10.6822 & -5.9668 & & \\
35 & 9.9649 & -6.14479 & 9.1687 & -0.0111 \\
40 & 9.1626 & -5.76439 & & \\
45 & 7.9286 & -5.47402 & & \\
50 & 7.9285 & -5.56009 & & \\
\hline
\end{tabular}

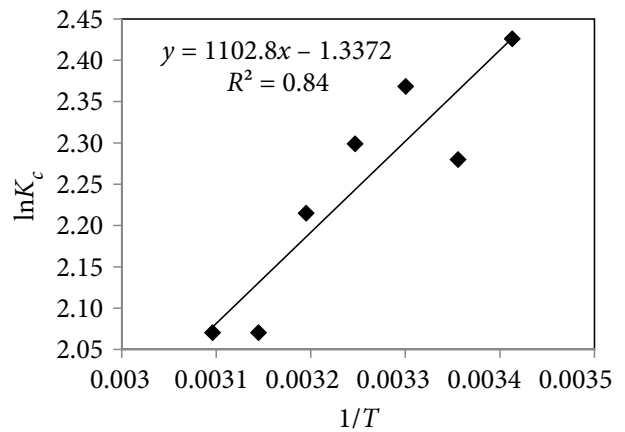

Fig. 11. Van $\mathrm{t}^{\prime} \mathrm{Hoff}$ graph of $\mathrm{Cu}^{2+}$ biosorption for temperatures in between $20-50{ }^{\circ} \mathrm{C}$

Table 4. Comparison of biosorption studies carried out with various biosorbent/adsorbents

\begin{tabular}{|c|c|c|c|c|c|}
\hline & $\begin{array}{c}q_{e^{\prime}} \\
\mathrm{mg} / \mathrm{g}\end{array}$ & $X(\mathrm{~g} / \mathrm{L})$ & $\begin{array}{c}\mathrm{Cu}^{2+} \\
(\mathrm{mg} / \mathrm{L})\end{array}$ & $\mathrm{pH}$ & References \\
\hline $\begin{array}{l}\text { Waste } \\
\text { eggshell }\end{array}$ & 6.48 & $0.5-5$ & $15-35$ & $2-5$ & $\begin{array}{l}\text { Polat, Aslan } \\
\text { (2014) }\end{array}$ \\
\hline $\begin{array}{l}\text { Lobaria } \\
\text { pulmonaria } \\
\text { (L.) }\end{array}$ & 65.3 & $1-50$ & $5-100$ & $2-6$ & $\begin{array}{l}\text { Kilıç et al. } \\
(2014)\end{array}$ \\
\hline Sawdust & 3.89 & 4 & $10-200$ & $2-6$ & $\begin{array}{l}\text { Putra et al. } \\
\text { (2014) }\end{array}$ \\
\hline Eggshell & 34.48 & 4 & $10-200$ & $2-6$ & $\begin{array}{l}\text { Putra et al. } \\
(2014)\end{array}$ \\
\hline Sugar cane & 3.65 & 4 & $10-200$ & $2-6$ & $\begin{array}{l}\text { Putra et al. } \\
(2014)\end{array}$ \\
\hline $\begin{array}{l}\text { Eichhornia } \\
\text { crassipes }\end{array}$ & 27.7 & 0.3 & $2-25$ & $2.5-6$ & $\begin{array}{l}\text { Komy et al. } \\
(2013)\end{array}$ \\
\hline $\begin{array}{l}\text { Waste } \\
\text { sludge }\end{array}$ & 19.34 & $0.1-1$ & $25-300$ & $2-7$ & $\begin{array}{l}\text { Güler, } \\
\text { Sarığlu } \\
(2013)\end{array}$ \\
\hline $\begin{array}{l}\text { S. cerevisiae } \\
\text { (maya) }\end{array}$ & 8.25 & $0.1-1$ & $25-300$ & $2-7$ & $\begin{array}{l}\text { Güler, } \\
\text { Sarığlu } \\
(2013)\end{array}$ \\
\hline $\begin{array}{l}\text { Rhizopus } \\
\text { oryzae }\end{array}$ & 34.2 & 0.1 & $10-300$ & $3-3,5$ & $\begin{array}{l}\text { Fu et al. } \\
(2012)\end{array}$ \\
\hline Grass & 58.34 & $0.5-2$ & $10-100$ & $1-8$ & $\begin{array}{l}\text { Hossain } \\
\text { et al. (2012) }\end{array}$ \\
\hline $\begin{array}{l}\text { Mangrov } \\
\text { shell }\end{array}$ & 6.95 & $1-3$ & $10-100$ & $2-10$ & $\begin{array}{l}\text { Rozaini } \\
\text { et al. }(2010)\end{array}$ \\
\hline Lentils shell & 15.62 & $0.5-0.8$ & $\begin{array}{c}100- \\
500\end{array}$ & $2-6$ & $\begin{array}{l}\text { Aydın et al. } \\
(2008)\end{array}$ \\
\hline Wheat shell & 11.0 & $0.5-0.8$ & $\begin{array}{c}100- \\
500\end{array}$ & $2-6$ & $\begin{array}{l}\text { Aydın et al. } \\
(2008)\end{array}$ \\
\hline Brass shell & 3.60 & $0.5-0.8$ & $\begin{array}{c}100- \\
500\end{array}$ & $2-6$ & $\begin{array}{l}\text { Aydın et al. } \\
(2008)\end{array}$ \\
\hline $\begin{array}{l}\text { Tobacco } \\
\text { leaf }\end{array}$ & 14.36 & 1 & 25 & 4 & This study \\
\hline
\end{tabular}




\section{Conclusions}

The present study revealed that tobacco sorbent could reliably be used to remove $\mathrm{Cu}^{2+}$ ions from aqueous solutions. The following conclusions can be drawn from the present study:

1. COD, TN and TP analyses were carried out at different biosorbent quantities and increasing values were observed with increasing biosorbent quantities.

2. A significant change was not observed in biosorbent capacity after a shaking rate of $100 \mathrm{rpm}$.

3. The amount of COD released to ambient with temperature was also investigated and significant effects of temperature on COD release were not observed.

4. The data on $\mathrm{Cu}^{2+}$ ion biosorption onto tobacco were applied to Langmuir, Freundlich, Temkin and D-R (Dubinin-Radushkevich) isotherm models. The resultant correlations coefficients were relatively high in all models.

5. Kinetic tests revealed that pseudo second-order kinetic model might better define the biosorption system.

It was concluded in this study that tobacco biosorbent had high $\mathrm{Cu}^{2+}$ removal efficiency (90.72\%) but it resulted in organic-originated pollution over biosorption system.

\section{References}

Aksu, Z.; Akpınar, D. 2000. Modelling of simultaneous biosorption of phenol and nickel(II) onto dried aerobic activated sludge, Separation and Purification Technology 21: 87-99. http://dx.doi.org/10.1016/S1383-5866(00)00194-5

Aksu, Z. 2001. Equilibrium and kinetic modelling of cadmium (II) biosorption by C.vulgaris in a batch systems: effect of temperature, Seperation and Purification Technology 21: 285294. http://dx.doi.org/10.1016/S1383-5866(00)00212-4

Aksu, Z. 2002. Determination of the equilibrium, kinetic and thermodynamic parametres of the biosorption of nickel(II) ions onto Chlorella vulgaris, Process Biochemistry 38: 89-99. http://dx.doi.org/10.1016/S0032-9592(02)00051-1

Allen, S. J.; McKay, G.; Porter, J. F. 2004. Adsorption isotherm models for basic dye adsorption by peat in single and binary component systems, Journal of Colloid and Interface Science 280: 322-333. http://dx.doi.org/10.1016/j.jcis.2004.08.078

Allen, S. J.; Gan, Q; Matthews, R.; Johnson, P. A. 2003. Comparison of optimised isotherm models for basic dye adsorption by kuzdu', Bioresour Technology 88(2): 143-52. http://dx.doi.org/10.1016/S0960-8524(02)00281-x

Al-Rub, F. A. A.; El-Naas, M. H.; Benyahia, F.; Ashour, I. 2004. Biosorption of nickel on blank alginate beads, free and immobilized algal cells, Process Biochemistry 39: 1767-1773. http://dx.doi.org/10.1016/j.procbio.2003.08.002

Al-Qodah, Z. 2006. Biosorption of heavy metal 1ons from aqueous solution by activated sludge, Desalination 196: 164-176. http://dx.doi.org/10.1016/j.desal.2005.12.012
Aydın, H.; Buluta, Y.; Yerlikaya, Ç. 2008. Removal of copper (II) from aqueous solution by adsorption onto low-cost adsorbents, Journal of Environmental Management 87: 37-45. http://dx.doi.org/10.1016/j.jenvman.2007.01.005

Başıbüyük, M.; Forster, C. F. 2003. An examination of adsorption characteristics of basic dye on to live activated sludge system, Process Biochemistry 38: 1311-1316. http://dx.doi.org/10.1016/S0032-9592(02)00327-8

Ceyhan, Ö.; Baybaş, D. 2001. Adsorption of some textile dyes by Hexadecyltrimethylammonium bentonite, Turk Journal Chemistry 25: 193-200.

Churchill, S. A.; Walters, J. V.; Churchill, P. F. 1995. Sorption of heavy metals by prepared bacterial cell surfaces, Journal of Environmental Engineering 121(10): 706-711. http://dx.doi. org/10.1061/(ASCE)0733-9372(1995)121:10(706)

Cruz, C. V. C; Da Costa, A. C. A.; Henriques, C. A.; Luna, A. S. 2004. Kinetic modelling and equilibrium studies during cadmium biosorption by dead Sargassum sp. biomass, Bioresource Technology 91: 249-257.

http://dx.doi.org/10.1016/S0960-8524(03)00194-9

Davis, T. A.; Volesky, B.; Mucci, A. A. 2003. Review of the biochemistry of heavy metal biosorption by brown algae, Water Research 37: 4311-4330. http://dx.doi.org/10.1016/S0043-1354(03)00293-8

Doğan, M.; Alkan, M. 2003. Removal of methly violet from aqueous solution by perlite, Journal of Colloid and Interface Science 267(1): 32-41. http://dx.doi.org/10.1016/S0021-9797(03)00579-4

Dubinin, M. M.; Radushkevich, L. V. 1947. Equation of the characteristic curve of activated charcoal, Chemistry Zentralblatt 1: 875.

Fu, Y. Q.; Li, S.; Zhu, H. Y.; Jiang, R.; Yin, L. F. 2012. Biosorption of copper (II) from aqueous solution by mycelial pellets of Rhizopus oryzae, African Journal of Biotechnology 11(6): 1403-1411.

Ghasemi, Z.; Seif, A.; Ahmadi, T. S.; Zargar, B.; Rashidi, F.; Rouzbahani, G. M. 2012. Thermodynamic and kinetic studies for the adsorption of $\mathrm{Hg}(\mathrm{II})$ by nano- $\mathrm{TiO}_{2}$ from aqueous solution, Advanced Powder Technology 23(2): 148-156. http://dx.doi.org/10.1016/j.apt.2011.01.004

Ghoreishi, S. M.; Haghighi, R. 2003. Chemical catalytic reaction and biological oxidation for treatment of non-biodegradable textile effluent, Chemical Engineering Journal 95: 163-152. http://dx.doi.org/10.1016/S1385-8947(03)00100-1

Gong, R.; Ding, Y. D.; Liu, H.; Chen, Q.; Liu, Z. 2005. Lead biosorption by intact and pretreated spirulina maxima biomass, Chemosphere 58: 125-130.

http://dx.doi.org/10.1016/j.chemosphere.2004.08.055

Güler, U. A.; Sarioglu, M. C. 2013. Mono and binary component biosorption of $\mathrm{Cu}(\mathrm{II}), \mathrm{Ni}(\mathrm{II})$, and Methylene Blue onto raw and pretreated S. cerevisiae: equilibrium and kinetics, Desalination and Water Treatment 52 (25-27): 4871-4888. http://dx.doi.org/10.1080/19443994.2013.810359

Gülnaz, O.; Saygideger, S.; Kusvuran, E. 2005. Study of Cu(II) biosorption by dried activated sludge: effect of physicochemical environment and kinetics study, Journal of Hazardous Materials B120: 193-200. http://dx.doi.org/10.1016/j.jhazmat.2005.01.003

Hasan, S.; Ghosh, T. K.; Viswanath, D. S.; Boddu, V. M. 2008. Dispersion of chitosan on perlite for enhancement of copper (II) adsorption capacity, Journal of Hazardous Materials 152: 826-837. http://dx.doi.org/10.1016/j.jhazmat.2007.07.078 
Ho, Y. S.; McKay, G. 1999. Pseudo-second order model for sorption processes, Process Biochemistry 34: 451-465. http://dx.doi.org/10.1016/S0032-9592(98)00112-5

Ho, Y. S.; Chiang, C. C. 2001. Sorption studies of acid dye by mixed sorbents, Adsorption 7: 139-147. http://dx.doi.org/10.1023/A:1011652224816

Ho, Y. S. 2003. Removal of copper ions from aqueous solution by tree fern, Water Research 37: 2323-2330. http://dx.doi.org/10.1016/S0043-1354(03)00002-2

Ho, Y. S.; Wang, C. C. 2004. Pseudo-ishotherms for the sorption of cadmium ions onto tree fern, Process Biochemistry 39: 759-763. http://dx.doi.org/10.1016/S0032-9592(03)00184-5

Horsfall, M. Jnr.; Abia, A. A.; Spıff, A. I. 2003. Removal of Cu (II) and $\mathrm{Zn}$ (II) ions from wastewater by Cassava (Manihot esculenta Cranz) waste biomass, African Journal of Biotechnology 2: 360-364. http://dx.doi.org/10.5897/AJB2003.000-1074

Hossain, M. A.; Ngo, H. H.; Guo, W. S.; Setiati, T. 2012. Adsorption and desorption of copper(II) ions onto garden grass, Bioresource Technology 121: 386-395.

http://dx.doi.org/10.1016/j.biortech.2012.06.119

Ip, A. W. M.; Barford J. P.; McKay, G. 2010. A comparative study on the kinetics and mechanism of removal of reactive Black 5 by adsorption onto activated carbons and bone char, Chemical Engineering Journal 157: 434-442. http://dx.doi.org/10.1016/j.cej.2009.12.003

Ju, D. J.; Byun, I. G.; Park, J. J; Lee, C. H.; Ahn, G. H.; Park, T. J. 2008. Biosorption of a reactive dye (Rhodamine-B) from an aqueous solution using dried biomass of activated sludge, Bioresource Technology 99: 7971-7975. http://dx.doi.org/10.1016/j.biortech.2008.03.061

Kalavathy, M. H.; Karthikeyan, T.; Rajgopal, S.; Miranda, L. R. 2005. Kinetic and isotherm studies of $\mathrm{Cu}$ (II) adsorption onto H3PO4-activated rubber wood sawdust, Journal of Colloid and Interface Science 292: 354-362.

http://dx.doi.org/10.1016/j.jcis.2005.05.087

Keskinkan, O.; Göksu, M. Z. L.; Başıüyük, M.; Forster, C. F. 2004. Heavy metal adsorption properties of submerged aquatic plant (Ceratophyllum demersum), Bioresource Technology 92: 197-200. http://dx.doi.org/10.1016/j.biortech.2003.07.011

Kılıç, M.; Apaydın-Varol, E.; Pütün, A. E. 2011. Adsorptive removal of phenol from aqueous solutions on activated carbon prepared from tobacco residues: equilibrium, kinetics and thermodynamics, Journal of Hazardous Materials 189: 397403. http://dx.doi.org/10.1016/j.jhazmat.2011.02.051

Kılıç, Z.; Atakol, O.; Aras, S.; Duman, D. C.; Çelikkol, P.; Emregül, E. 2014. Evaluation of different isotherm models, kinetic, thermodynamic, and copper biosorption efficiency of Lobaria pulmonaria (L.) Hoffm., Journal of the Air \& Waste Management Association 64(1): 115-123.

http://dx.doi.org/10.1080/10962247.2013.831383

Komy, Z. R.; Abdelraheem, W. H.; Ismail, N. M. 2013. Biosorption of $\mathrm{Cu}^{2+}$ by Eichhornia crassipes: physicochemical characterization, biosorption modeling and mechanism, Journal of King Saud University - Science 25: 47-56.

Liu, H.; Chen, B.; Lana, Y.; Chenga, Y. 2004. Biosorption of $\mathrm{Zn}(\mathrm{II})$ and $\mathrm{Cu}(\mathrm{II})$ by the indigenous Thiobacillus thiooxidans, Chemistry Engineering Journal 97: 195-201. http://dx.doi.org/10.1016/S1385-8947(03)00210-9

Lodeiro, P.; Cordero, B.; Barriada, J. L.; Herrero, R.; Sastre de Vicente, M. E. 2005. Biosorption of cadmium by biomass of brown marine macroalgae, Bioresource Technology 96: 17961803. http://dx.doi.org/10.1016/j.biortech.2005.01.002
Majumdar, S. S.; Das, S. K.; Saha, T.; Panda, G. C; Bandyopadhyoy, T.; Guha, A. K. 2008. Adsorption behavior of copper ions on Mucor rouxii biomass through microscopic and FTIR analysis, Colloids and Surfaces B: Biointerfaces 63: 138145. http://dx.doi.org/10.1016/j.colsurfb.2007.11.022

Malik, U. R.; Hasany, S. M.; Subhani, M. S. 2005. Sorptive potential of sunflower stem for $\mathrm{Cr}(\mathrm{III})$ ions from aqueous solutions and its kinetic and thermodynamic profile, Talanta 66: 166-173. http://dx.doi.org/10.1016/j.talanta.2004.11.013

Martins, R. J. E.; Pardo, R.; Boaventura, R. A. R. 2004. Cadmium (II) and zinc (II) adsorption by the aquatic moss Fontinalis antipyretica: effect of temperature, $\mathrm{pH}$ and water hardness, Water Research 38: 693-699. http://dx.doi.org/10.1016/j.watres.2003.10.013

Özer, A.; Gürbüz, G.; Çalımlı, A.; Körbahtii B. K. 2009. Biosorption of copper(II) ions on Enteromorpha prolifera: Application of response surface methodology (RSM), Chemical Engineering Journal 146: 377-387. http://dx.doi.org/10.1016/j.cej.2008.06.041

Padmavathy, V. 2008. Biosorption of nickel(II) ions by baker's yeast: Kinetic, thermodynamic and desorption studies, Bioresource Technology 99: 3100-3109. http://dx.doi.org/10.1016/j.biortech.2007.05.070

Pahlavanzadeh, H.; Keshtkar, A. R.; Safdari, J.; Abadi, Z. 2010. Biosorption of nickel(II) from aqueous solution by brown algae: equilibrium, dynamic and thermodynamic studies, Journal of Hazardous Materials 175: 304-310. http://dx.doi.org/10.1016/j.jhazmat.2009.10.004

Polat, A.; Aslan, S. 2014. Kinetic and isotherm study of cupper adsorption from aqueous solution using waste eggshell, Journal of Environmental Engineering and Landscape Management 22(2): 132-140. http://dx.doi.org/10.3846/16486897.2013.865631

Pradhan, S.; Singh, S.; Rai, L. C. 2007. Characterization of various functional groups present in the capsule of Microcystis and study of their role in biosorption of $\mathrm{Fe}, \mathrm{Ni}$ and $\mathrm{Cr}$, Bioresource Technology 98: 595-601. http://dx.doi.org/10.1016/j.biortech.2006.02.041

Putra, W. P.; Kamari, A.; Yusoff, S. N. M.; Ishak, C. F.; Mohamed, A.; Hashim, N.; Isa, I. M. 2014. Biosorption of $\mathrm{Cu}(\mathrm{II})$, $\mathrm{Pb}(\mathrm{II})$ and $\mathrm{Zn}$ (II) ions from aqueous solutions using selected waste materials: adsorption and characterisation studies, Journal of Encapsulation and Adsorption Sciences 4: 25-35. http://dx.doi.org/10.4236/jeas.2014.41004

Rozaini, C. A.; Jain, K.; Oo, C. W.; Tan, K. W.; Tan, L. S.; Azraa, A.; Tong, K. S. 2010. Optimization of nickel and copper ions removal by modified mangrove barks, International Journal of Chemical Engineering and Applications 1(1): 84-89. http://dx.doi.org/10.7763/IJCEA.2010.V1.14

Sarı, A.; Mendil, D.; Tuzen, M.; Soylak, M. 2008. Biosorption of $\mathrm{Cd}(\mathrm{II})$ and $\mathrm{Cr}$ (III) from aqueous solution by moss (Hylocomium splendens) biomass: equilibrium, kinetic and thermodynamic studies, Chemical Engineering Journal 144: 1-9. http://dx.doi.org/10.1016/j.cej.2007.12.020

Sawalha, M. F.; Videa, J. R. P.; Gonz'alez, J. R.; Gardea-Torresdey, J.L. 2006. Biosorption of Cd(II), Cr(III), and Cr(VI) by Saltbush (Atriplex canescens) biomass: thermodynamic and isotherm studies, Journal Colloid Interface Science 300: 100-104. http://dx.doi.org/10.1016/j.jcis.2006.03.029

Temkin, M. J.; Phyzev, V. 1940. Recent modifications to Langmuir isotherms, ActaPhysiochim USSR 12: 217-222. 
Topal, M.; Arslan Topal, E. I.; Aslan, S. 2011. Removal of Cu(II) from aqueous solutions by using lemon peel, Erciyes University of the Journal Institute of Science and Technology 27(3): 265-270.

Volesky, B. 2001. Detoxification of metal-bearing effluents biosorption for the next century, Hydrometallurgy 59: 203-216. http://dx.doi.org/10.1016/S0304-386X(00)00160-2

Wang, J.; Chen, C. 2006. Biosorption of heavy metals by Saccharomyces cerevisiae: a review, Biotechnology Advances 24: 427-451. http://dx.doi.org/10.1016/j.biotechadv.2006.03.001
Weber, J. R. 1972. Physicochemical processes for water quality control. USA: Willey Interscience.

Yazıc1, H. 2007. The investigation of the biosorption of $\mathrm{Cr}$ and $\mathrm{Cu}^{2+}$ ions from aqueous solutions by marrubium globosum ssp. globosum plant: M. Sc. Thesis. Isparta: Süleyman Demirel University Graduate School of Applied and Natural Sciences Department of Environmental Engineering. 140 p.

Mehmet ÇEKIM. He is a Master Student at the Department of Environmental Engineering, Cumhuriyet University, Sivas. Research interests include biosorption and wastewater treatment.

Sayiter YILDIZ, Dr Lecturer at the Department of Environmental Engineering, Cumhuriyet University, Sivas. His research interests include heavy metal removal, sewage sludge, sorption.

Turgay DERE, Dr Lecturer at the Department of Environmental Engineering, Adiyaman University, Adiyaman. His research interests include heavy metal removal, sorption. 